\title{
Expression of CD 40 ligand, interferon-gamma and Fas ligand genes in endomyocardial biopsies of human cardiac allografts: correlation with acute rejection
}

N. Shulzhenko ${ }^{1}, A$. M orgun $^{1}$, M. Franco ${ }^{2}$, M.M. Souza2, D.R. Almeida ${ }^{3}$, R.V.Z. Diniz ${ }^{3}$, A.C.C. Carvalho ${ }^{3}$, A. Pacheco-Silva ${ }^{3}$ and M. Gerbase-D eLima ${ }^{1}$

\author{
Departamentos de ${ }^{1}$ Pediatria, ${ }^{2}$ Patologia, and \\ ${ }_{3}^{3}$ Medicina, Escola Paulista de Medicina, \\ Universidade Federal de São Paulo, São Paulo, SP, Brasil
}

\section{Correspondence \\ N. Shulzhenko \\ Rua dos 0 tonis, 725 \\ 04025-002 São Paulo, SP \\ Brasil \\ Fax: + 55-11-5576-4426/5579-1590/ \\ 5574-0548 \\ E-mail: anemorgun@ hotmail.com}

Research supported by FAPESP (No. 98/14715-0) and CNPq (No. 305330/ 76). N. Shulzhenko and A. Morgun are recipients of FAPESP fellowships.

Received May 9, 2000 Accepted February 21, 2001

\section{Abstract}

The purpose of the present study was to investigate the expression (mRNA) of CD40 ligand (CD40L), interferon- $\gamma$ (IFN- $\gamma$ ) and Fas ligand (FasL) genes in human cardiac allografts in relation to the occurrence of acute cardiac allograft rejection as well as its possible value in predicting acute rejection. The mRNA levels were determined by a semiquantitative reverse transcriptase-polymerase chain reaction method in 39 samples of endomyocardial biopsies obtained from 10 adult cardiac transplant recipients within the first six months after transplantation. Biopsies with ongoing acute rejection showed significantly higher CD40L, IFN- $\gamma$ and FasL mRNA expression than biopsies without rejection. The median values of mRNA expression in biopsies with and without rejection were 0.116 and zero for CD40L $(\mathrm{P}<0.003), 0.080$ and zero for IFN- $\gamma(\mathrm{P}<0.0009)$, and 0.156 and zero for FasL $(\mathrm{P}<0.002)$, respectively. In addition, the levels of IFN- $\gamma$ mRNA were significantly increased 7 to 15 days before the appearance of histological evidence of rejection (median of 0.086 in prerejection biopsies), i.e., they presented a predictive value. This study provides further evidence of heightened expression of immune activation genes during rejection and shows that some of these markers may present predictive value for the occurrence of acute rejection.
Key words

- Rejection

- Cardiac allograft

- Immunologic monitoring

- mRNA

- Gene activation

- Interferon-gamma
Cardiac transplantation is an effective therapy for end-stage heart disease, but the occurrence of rejection is a major hazard following transplantation. Acute rejection occurs in more than $50 \%$ of heart transplant recipients, is the leading cause of death in the first year and accounts for approximately
$20 \%$ of all deaths following heart transplantation $(1,2)$. The "gold standard" for the diagnosis of rejection is the histological evaluation of endomyocardial biopsies and the most commonly used grading scale for the diagnosis and staging of rejection is that of the International Society for Heart and Lung 
Transplantation (ISHLT) (3). Nonetheless, the histological evaluation of endomyocardial biopsies may present problems of sensitivity and does not always allow discrimination between mild episodes of rejection which might be self-limiting from those that may progress $(4,5)$. Therefore, much effort is being devoted to other procedures that could be of additive value to histological grading and/or that could indicate the onset of a rejection process before the appearance of histological alterations. In this setting, immunologic markers have been explored both in biopsies and in peripheral blood. Although interesting results have been reported, the perfect marker(s) remain to be established (2,6-16).

In a previous study using a qualitative reverse transcriptase-polymerase chain reaction (RT-PCR) assay, we have shown a higher rate of detection of mRNA for CD40 ligand (CD40L), interferon- $\gamma($ IFN- $\gamma$ ), IL-8, granzyme B and Fas ligand (FasL) in endomyocardial biopsies with histological features of rejection, as well as an increased frequency of detection of IFN- $\gamma$ and IL-8 mRNA in biopsies that did not show histological alterations but were preceded or followed by rejection within an interval of 7 to 15 days $(17,18)$. These results, however, could not be accepted as definitive, since the qualitative RT-PCR assay has the drawback of not taking into consideration the amount of total mRNA present in the sample.

In order to further investigate the relationship between acute cardiac allograft rejection and the expression of mRNA of immune activation molecules, we have used a semiquantitative RT-PCR assay to determine the level of activation of the CD40L, IFN- $\gamma$ and FasL genes in the same biopsy samples as used in the above mentioned study. The semiquantitative RT-PCR assay is superior to the qualitative assay since the level of transcription of the gene under study is normalized by the expression of a gene whose transcription level is constant (19).
The results herein reported refer to data obtained for 39 endomyocardial biopsy samples collected during the first six months after transplantation from 10 adult cardiac allograft recipients. The protocol was approved by the Ethics Committee of the Federal University of São Paulo and informed consent was obtained from all subjects under study. All patients were maintained on standard triple immunosuppression therapy. Treatment for rejection consisted of pulse therapy with methylprednisolone ( $1 \mathrm{~g}$ daily for 3 days) and/or augmentation of the oral doses of prednisone and cyclosporine. Pathologic assessment was performed by two pathologists who were unaware of the mRNA study results. Rejection was graded according to ISHLT criteria after the examination of three or four fragments of each endomyocardial biopsy. One fragment of the biopsy was snap-frozen and stored in liquid nitrogen until the time for mRNA extraction. The study comprised 19 biopsies with rejection (ISHLT grade $\geq 1 \mathrm{~B}$, with two biopsies being grade $1 \mathrm{~B}$, one grade 2,15 grade $3 \mathrm{~A}$, and one grade $3 \mathrm{~B}$ ), six without histological signs (grade 0 biopsies) of rejection and collected 7 to 15 days prior to the histological diagnosis of rejection (pre-rejection endomyocardial biopsies), and 14 without histological signs of rejection and collected more than 15 days before or after the day when the diagnosis of rejection was established (endomyocardial biopsies without rejection).

Experiments to optimize the amplification conditions for each set of primers were performed with mRNA extracted from phytohemagglutinin-stimulated (Difco, Detroit, MI, USA) peripheral blood mononuclear cells from a normal donor, as previously described (17). After a 48-h incubation period, the cells from 10 wells were pooled, pelleted, and resuspended in $0.4 \mathrm{ml}$ of extraction buffer (QuickPrep Micro mRNA Purification Kit, Pharmacia Biotech, Uppsala, Sweden). The other steps of mRNA extraction were performed according to manufacturer instructions. 
The biopsy fragment was placed in 0.4 $\mathrm{ml}$ extraction buffer and homogenized with a Handishear AC homogenizer (VirTis Company, Gardiner, NY, USA) and the extracted mRNA was resuspended in $60 \mu 1$ of diethylpolycarbonate-treated water $(0.1 \mathrm{~g} \%)$.

Reverse transcription was performed on $19 \mu \mathrm{l}$ of the isolated mRNA with $2 \mu \mathrm{l}$ of Moloney murine leukemia virus reverse transcriptase (200 U/ $\mu 1$; Gibco-BRL, Gaithersburg, MD, USA), $2 \mu 1$ of oligo(dT) ${ }_{12-18}$ primer at $100 \mu \mathrm{g} / \mathrm{ml}$ (Pharmacia Biotech), and $10 \mu \mathrm{l}$ of $10 \mathrm{mM}$ dNTPs (Pharmacia Biotech). The remaining components of the mixture were $10 \mu 1$ of reverse transcription buffer, $5 \mu l$ of $0.1 \mathrm{M}$ dithiothreitol solution, $1 \mu 1$ of bovine serum albumin at $1 \mathrm{mg} / \mathrm{ml}$ (all from Gibco $\mathrm{BRL})$, and $2 \mu \mathrm{l}(20 \mathrm{U})$ of placental ribonuclease inhibitor (Pharmacia Biotech). This mixture was first incubated at $37^{\circ} \mathrm{C}$ for 60 min, and then at $65^{\circ} \mathrm{C}$ for $10 \mathrm{~min}$.

Primers used in PCR were synthesized by Gibco BRL and the sense (S) and antisense (AS) sequences of the oligonucleotides were as follows: ß-actin - S: 5' CGTGACATTAA GGAGAAGCTG 3', AS: 5' CTCAGGAGG AGCAATGATCTTGA 3' (product size 375 bp); CD40L - S: 5' CGGAACTGTGGGTAT TT 3', AS: 5' ACTTTTTGCTGTGTATC 3' (product size $520 \mathrm{bp}$ ); IFN- $\gamma$ - $\mathrm{S}: 5^{\prime}$ CCAGAG CATCCAAAAGAGTGTG 3', AS: 5' CTAG TTGGCCCCTGAGATAAAG 3' (product size 510 bp); FasL - S: 5' GCCTGTGTCTCC TTGTGA 3', AS: 5' GCCACCCTTCTTAT ACTT 3' (product size $321 \mathrm{bp}$ ).

Sterile injection-grade water was used instead of cDNA as a negative control. The reaction mixture for PCR amplification consisted of $5 \mu \mathrm{l}$ of cDNA, $10 \mathrm{mM}$ of each $\mathrm{dNTP}, 250 \mathrm{ng}$ of each primer, $5 \mu \mathrm{l}$ of $10 \mathrm{X}$ concentrated PCR buffer, $2.5 \mathrm{mM} \mathrm{MgCl}$, and 2.5 U of Taq polymerase (Cenbiot, Porto Alegre, RS, Brazil) in a total volume of 50 $\mu 1$. Samples were denatured at $94^{\circ} \mathrm{C}$ for $60 \mathrm{~s}$, annealed at $55^{\circ} \mathrm{C}$ for $45 \mathrm{~s}$, and extended at $72^{\circ} \mathrm{C}$ for $45 \mathrm{~s}$. This cycle was carried out 40 times in a thermocycler (GeneAmp PCR System 9600, Perkin Elmer Cetus, Norwalk, CT, USA). All samples were initially tested with the $B$-actin primers, as a control for successful RNA extraction and cDNA amplification. Thereafter, the samples were tested in duplicate with the primers for each marker, in parallel with primers for $\beta$-actin.

Table 1. CD40L, IFN- $\gamma$, and FasL mRNA levels (target mRNA/ß-actin mRNA) in endomyocardial biopsies.

\begin{tabular}{|c|c|c|c|c|c|c|c|}
\hline \multirow[t]{2}{*}{ Biopsies } & \multirow[t]{2}{*}{ Number } & \multicolumn{3}{|c|}{$\begin{array}{c}\text { Median mRNA } \\
\text { levels }\end{array}$} & \multicolumn{3}{|c|}{$\begin{array}{l}\text { Percentage of positive } \\
\text { biopsies (mRNA } \\
\text { expression >zero)* }\end{array}$} \\
\hline & & CD40L & IFN- $\gamma$ & FasL & CD40L & $\mathrm{IFN}-\gamma$ & FasL \\
\hline $\begin{array}{l}\text { Without histological evidence of rejection } \\
\text { (grade } 0 \text { ) and collected at least } 15 \text { days } \\
\text { before or after rejection }\end{array}$ & 14 & 0 & 0 & 0 & $\begin{array}{c}28.6 \\
(4 / 14)\end{array}$ & $\begin{array}{l}21.4 \\
(3 / 14)\end{array}$ & $\begin{array}{l}42.8 \\
(6 / 14)\end{array}$ \\
\hline $\begin{array}{l}\text { Pre-rejection, i.e., without histological } \\
\text { evidence of rejection (grade } 0 \text { ) and } \\
\text { collected } 7 \text { to } 15 \text { days before rejection }\end{array}$ & 6 & 0.036 & 0.086 & 0.042 & $\begin{array}{l}66.6 \\
(4 / 6)\end{array}$ & $\begin{array}{l}83.3 \\
(5 / 6)\end{array}$ & $\begin{array}{l}66.6 \\
(4 / 6)\end{array}$ \\
\hline With rejection (at least ISHLT grade $\geq 1 \mathrm{~B}$ ) & $16-19$ & 0.116 & 0.080 & 0.156 & $\begin{array}{c}93.7 \\
(15 / 16)\end{array}$ & $\begin{array}{c}84.2 \\
(16 / 19)\end{array}$ & $\begin{array}{c}94.4 \\
(17 / 18)\end{array}$ \\
\hline
\end{tabular}

*Fisher's exact test: a) with rejection $x$ without rejection: CD40L, $P<0.003$; IFN- $\gamma, P<0.0009$; FasL, $P<0.002$; b) pre-rejection $x$ without rejection: $C D 40 L$, not significant; IFN- $\gamma, \mathrm{P}=0.006$; FasL, not significant; c) pre-rejection $x$ rejection: $C D 40 L, P<0.06$; IFN- $\gamma$, not significant; FasL, $P<0.02$. CD40L, CD40 ligand; IFN- $\gamma$, interferon- $\gamma$; FasL, Fas ligand. 


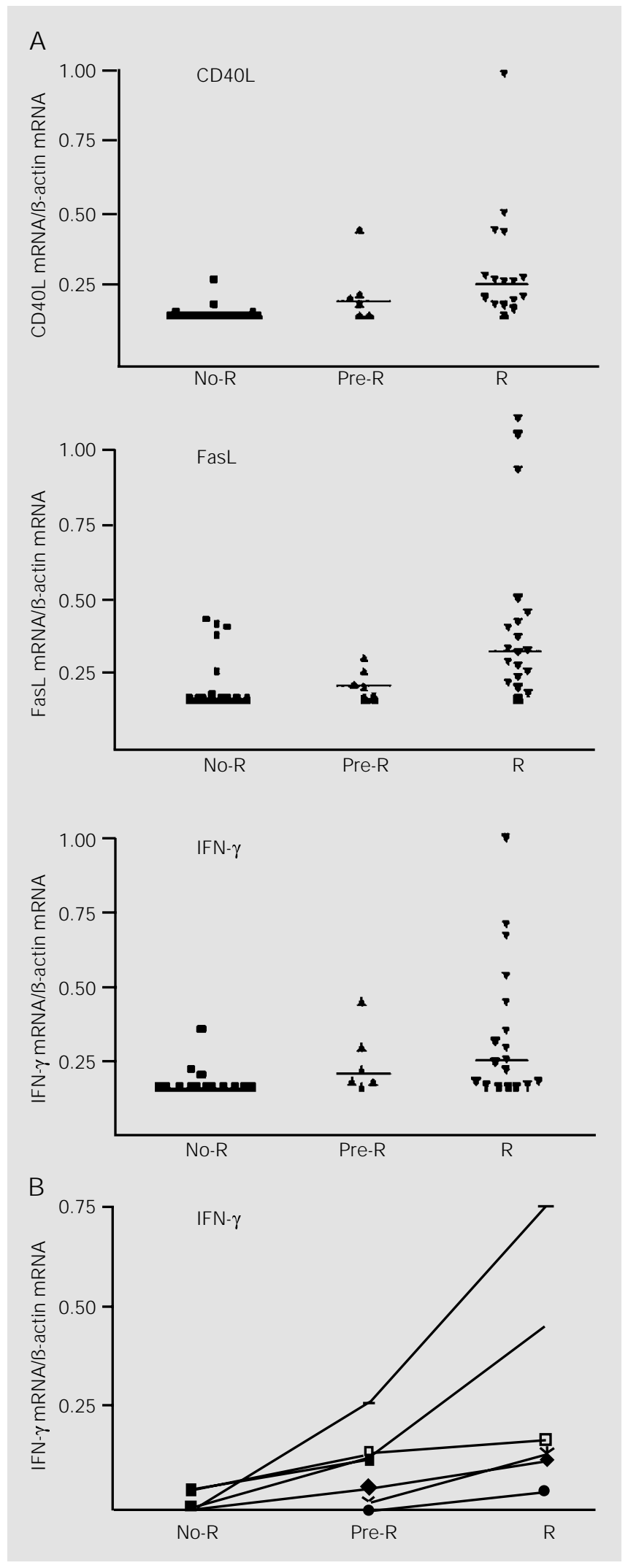

A $14-\mu 1$ aliquot of the PCR product was analyzed by electrophoresis on ethidium bromide-stained $2 \%$ agarose gels $(\mathrm{w} / \mathrm{v})$. Products were identified by comparison with a molecular weight marker ( $\phi-174-\mathrm{RF}$ DNA/ HincII Digest, Pharmacia Biotech). The image of the gel was captured with a Kodak DC120 zoom digital camera and the band intensity was measured using the Kodak Digital Science - Electrophoresis Documentation and Analysis System 120 software. The levels of expression of the markers were normalized by the $\beta$-actin expression level in each sample (intensity of the band of the marker/intensity of the $\beta$-actin band).

The median mRNA levels in the three groups of biopsies, as well as the percentage of biopsies positive for the markers, are presented in Table 1, and the individual values are shown in Figure 1A. As the majority of the no rejection biopsies did not present detectable mRNA levels of the markers, the quantitative data were transformed into qualitative data and the groups were compared by the Fisher exact test. A biopsy was considered to be positive for a given marker when its mRNA level was above the median value of the group without rejection, i.e., above the zero level. The number of positive biopsies was significantly higher in the rejection than in the no rejection group in respect to all the markers (CD40L, $\mathrm{P}<0.003$; IFN- $\gamma, \mathrm{P}<0.0009$; FasL, $\mathrm{P}<0.002$ ), while the number of positive biopsies in the pre-rejection group was

Figure 1. Expression of CD40L, IFN- $\gamma$ and FasL genes in endomyocardial biopsies. A, CD40L, FasL and IFN- $\gamma$ mRNA levels (target mRNA/ß-actin mRNA) in the samples without rejection collected more than 15 days before or after rejection (No-R), in the samples without rejection collected 7 to 15 days before rejection (Pre$\mathrm{R})$, and in the samples with rejection (R). The horizontal lines represent the median values. B, Kinetics of intragraft IFN- $\gamma$ mRNA levels in six patients for whom no rejection, pre-rejection, and rejection biopsy samples were available. Each line represents one patient. CD40L, CD40 ligand; IFN- $\gamma$, interferon- $\gamma$; FasL, Fas ligand. 
higher than in the no rejection group only regarding IFN- $\gamma$ mRNA expression $(\mathrm{P}<0.02)$. Figure 1B illustrates the kinetics of intragraft IFN- $\gamma$ mRNA expression in six patients for whom pre-rejection biopsies and the corresponding no rejection (in 4 cases) and rejection samples were available.

Among the six pre-rejection biopsies examined, only one failed to show an increment of IFN- $\gamma$ mRNA. It is interesting to note that while the five cases that presented increased IFN- $\gamma$ mRNA prior to rejection corresponded to typical reversible cellular acute rejection episodes, the one that did not present this increase was a case of irreversible rejection with histological features of vascular acute rejection. Furthermore, this recipient developed anti-HLA antibody during this rejection episode, representing the only one who did so among 12 cardiac allograft recipients (including all the recipients of the present study) previously investigated regarding post-transplant antilymphocytic antibody production (20).

The results of the present study confirm previous data reported by our group and others concerning increased intragraft expression of IFN- $\gamma$, CD40L and FasL genes $(9,11,14,17,18)$ during acute cardiac or kidney allograft rejection. More importantly, the present results also confirm our previous observation regarding the predictive value of increased IFN- $\gamma$ gene expression for the occurrence of acute cellular rejection $(17,18)$. Given the importance of the recognition of rejection to ensure proper immunosuppressive therapy, we propose the measurement of IFN- $\gamma$ mRNA levels in endomyocardial biopsies, especially during the critical initial six-month period when the incidence of rejection is at its peak. These levels could be used as a guide for early anti-rejection treatment or at least to indicate another biopsy within a shorter interval than that routinely scheduled. Considering the relatively small number of patients evaluated in the present study, further investigations are needed to define the sensitivity and specificity of this test.

\section{References}

1. Kobashigawa J Á, Kirklin J K, Naftel DC, Bourge RC, Ventura HO, Mohanty PK, Cintron GB \& Bhat G (1993). Pretransplantation risk factors for acute rejection after heart transplantation: a multiinstitutional study. The Transplant Cardiologists Research Database Group. J ournal of Heart and Lung Transplantation, 12: 355-366.

2. Cook DJ , Bishay ES \& Yamani M (2000). The use and misuse of immunologic monitoring after transplantation: approaches that have proved useful. Current Opinion in Cardiology, 15: 104-107.

3. Billingham ME, Cary NR, Hammond ME, Kemnitz J, Marboe C, McCallister HA, Snovar DC, Winters GL \& Zerbe A (1990). A working formulation for the standardization of nomenclature in the diagnosis of heart and lung rejection: Heart Rejection Study Group. The International Society for Heart and Lung Transplantation. J ournal of Heart and Lung Transplantation, 9: 587593.
4. Topalidis $\mathrm{T}$, Warnecke $\mathrm{H}$, Müller $\mathrm{G} \&$ Hetzer R (1990). Endomyocardial biopsies - the potential margin of error. Transplantation Proceedings, 22: 1443.

5. Nakhlen RE, J ones J , Gostwitz J J , Anderson EA \& Titus J (1992). Correlation of endomyocardial biopsy findings with autopsy findings in human cardiac allografts. J ournal of Heart and Lung Transplantation, 11: 479-485.

6. DeBruyne LA, Picotti J R \& Bishop DK (1996). Regulation of cardiac allograft rejection by $\mathrm{T}$ lymphocytes. Trends in Cardiovascular Medicine, 6: 168-173.

7. Alpert S, Lewis NP, Fowler M \& Valantine HA (1995). The relationship of granzyme $A$ and perforin expression to cardiac allograft rejection and dysfunction. Transplantation, 60: 1478-1485.

8. Baan CC, van Emmeric NEM, BalkAHMM, Quint WGV, Mochtar B, J utte NHPM, Niester HGM \& Weimar W (1994). Cytokine mRNA expression in endomyocar- dial biopsies during acute rejection from human heart transplants. Clinical and Experimental Immunology, 97: 293-298.

9. Reul RM, Fang J C, Denton MD, Geehan C, Long C, Mitchell RN, Ganz P \& Briscoe DM (1997). CD40 and CD40 ligand (CD154) are coexpressed on microvessels in vivo in human cardiac allograft rejection. Transplantation, 64: 1765-1774.

10. Grant SCD, Guy SP, Lamb WR, Brooks $\mathrm{NH}$, Brenchley PES \& Hutchinson IV (1996). Expression of cytokine messenger RNA after heart transplantation. Transplantation, 62: 910-916.

11. Strehlau J, Pavlakis M, Lipman M, Maslinski W, Shapiro M \& Strom TB (1996). The intragraft gene activation of markers reflecting T-cell-activation and -cytotoxicity analyzed by quantitative RT-PCR in renal transplantation. Clinical Nephrology, 46: 30-33.

12. Hosenpud J D, Bennett LE, Keck BM, Fiol $B$ \& Novick RJ (1997). The Registry of the 
International Society for Heart and Lung Transplantation: Fourteenth Official Report - 1997. J ournal of Heart and Lung Transplantation, 16: 691-712.

13. Kimball PM, Radovancevic B, Isom T, Spickard A \& Frazier OH (1996). The paradox of cytokine monitoring - predictor of immunologic activity as well as immunologic silence following cardiac transplantation. Transplantation, 61: 909-915.

14. Zheng $X X$, Schachter $A D$, Vasconcellos $L$, Strehlau J , Tian Y, Shapiro M, Harmon W $\&$ Strom TB (1998). Increased CD40 ligand gene expression during human renal and murine islet allograft rejection. Transplantation, 65: 1512-1515.

15. Ruan XM, Qiao JH, Trento A, Czer LS Blanche C \& Fishbein MC (1992). Cy- tokine expression and endothelial cell and lymphocyte activation in human cardiac allograft rejection. J ournal of Heart and Lung Transplantation, 11: 1110-1116.

16. Wu CJ , Lovett M, Wong-Lee J, M oeller F, Kitamura M, Goralski TJ , Billingham ME, Starnes VA \& Clayberger C (1992). Cytokine gene expression in rejecting cardiac allografts. Transplantation, 54: 326332.

17. Shulzhenko $N$, Morgun A, Franco $M$, Souza MM, Almeida DR, Diniz RVZ, Carvalho ACC, Pacheco-Silva A \& GerbaseDeLima M (2000). Expression of immune activation genes in biopsies after cardiac transplantation. Brazilian Pediatric News, 2 [serial online]. www.brazilpednews. org.br/mar2000. Accessed March 2000.
18. Shulzhenko $N$, Morgun A, Franco $M$, Souza MM, Almeida DR, Diniz RVZ, Carvalho ACC, Pacheco-Silva A \& GerbaseDeLima M (1999). Increased intragraft expression of immune activation genes in rejecting human cardiac allografts. Transplantation, 67: S266 (Abstract).

19. Dallman MJ (1998). Polymerase chain reaction methods in immunology. Transplantation Proceedings, 30: 2367-2369.

20. Morgun $A$, Shulzhenko N, Unterkirsher CS, Pereira AB, Silva MS, Nishida SK, Almeida DR, Diniz RVZ, Carvalho ACC, Franco M, Souza M M \& Gerbase-DeLima M (1999). Allo- and autoantibodies in human cardiac allograft recipients. Transplantation Proceedings, 31: 2976-2977. 